\title{
Antitumor activities of Aspiletrein A, a steroidal saponin from Aspidistra letreae, on non-small cell lung cancer cells
}

Hien Minh Nguyen ${ }^{1}$, Hoai Thi Nguyen², Suthasinee Seephan ${ }^{3}$, Hang Bich Do ${ }^{1}$, Huy Truong Nguyen ${ }^{1}$, Duc Viet $\mathrm{Ho}^{2^{*}}$ and Varisa Pongrakhananon ${ }^{4,5^{*}}$ (D)

\begin{abstract}
Background: Lung cancer is one of the leading causes of death worldwide due to its strong proliferative and metastatic capabilities. The suppression of these aggressive behaviors is of interest in anticancer drug research and discovery. In recent years, many plants have been explored in order to discover new bioactive secondary metabolites to treat cancers or enhance treatment efficiency. Aspiletrein A (AA) is a steroidal saponin isolated from the whole endemic species Aspidistra letreae in Vietnam. Previously, elucidation of the structure of AA and screening of its cytotoxic activity against several cancer cell lines were reported. However, the antitumor activities and mechanisms of action have not yet been elucidated. In this study, we demonstrated the anti-proliferative, anti-migrative and antiinvasive effects of AA on H460, H23 and A549 human lung cancer cells.
\end{abstract}

Methods: MTT, wound healing and Transwell invasion assays were used to evaluate the anti-proliferation, antimigration and anti-invasion effects of AA, respectively. Moreover, the inhibitory effect of AA on the activity of protein kinase $B$ (Akt), a central mediator of cancer properties, and apoptotic regulators in the $\mathrm{BCl}-2$ family proteins were investigated by Western blotting.

Results: AA exhibits antimetastatic effects in human lung cancer cells through the inhibition of the pAkt/Akt signaling pathway, which in turn resulted in a significant inhibitory effect of AA on the migration and invasion of the examined lung cancer cells.

Conclusions: Aspiletrein A may be a potent inhibitor of protein kinase B (Akt). Hence, AA could be further explored as a potential antimetastatic lead compound.

Keywords: Aspidistra letreae, Aspiletrein A, Anti-proliferation, Anti-migration, Anti-invasion, Lung cancer cells

\section{Background}

The incidence and mortality rates of cancer are sharply increasing every year. Globally, the burden of cancer increased to approximately 18.1 million new cases and 9.6 million deaths in 2018 [1, 2]. Lung cancer is one of the

\footnotetext{
* Correspondence: hvietduc@hueuni.edu.vn; varisa.p@pharm.chula.ac.th ${ }^{2}$ Faculty of Pharmacy, Hue University of Medicine and Pharmacy, Hue University, Hue City, Vietnam

${ }^{4}$ Department of Pharmacology and Physiology, Faculty of Pharmaceutical Sciences, Chulalongkorn University, Bangkok 10330, Thailand

Full list of author information is available at the end of the article
}

most commonly occurring cancers and common causes of death. It is divided into two types, small-cell lung carcinoma (SCLC) and non-small cell lung carcinoma (NSCLC) [3-6]. NSCLC accounts for the majority of lung cancer cases and exhibits a strong capacity for metastasis. Most patients are in an advanced stage at first diagnosis, and the survival rate of metastatic lung cancer patients is extremely low, at only 5\% [7]. Metastasis, one of the hallmark characteristics of cancer, comprises multiple processes: cancer detachment from primary organs, migration and invasion

C C The Author(s). 2021 Open Access This article is licensed under a Creative Commons Attribution 4.0 International License, which permits use, sharing, adaptation, distribution and reproduction in any medium or format, as long as you give appropriate credit to the original author(s) and the source, provide a link to the Creative Commons licence, and indicate if changes were made. The images or other third party material in this article are included in the article's Creative Commons licence, unless indicated otherwise in a credit line to the material. If material is not included in the article's Creative Commons licence and your intended use is not permitted by statutory regulation or exceeds the permitted use, you will need to obtain permission directly from the copyright holder. To view a copy of this licence, visit http://creativecommons.org/licenses/by/4.0/ The Creative Commons Public Domain Dedication waiver (http://creativecommons.org/publicdomain/zero/1.0/) applies to the data made available in this article, unless otherwise stated in a credit line to the data. 
through surrounding tissues, intravasation into systemic circulation, extravasation into secondary sites and secondary tumor establishment [8-10]. Several signaling pathways governing cancer aggressiveness, including protein kinase $\mathrm{B}$ (Akt), have been identified. Akt is a serine- and threoninespecific protein kinase that plays an important role as an oncogenic promotor [11]. An increase in active Akt or its phosphorylation (pAkt) enhances the cell growth, cell survival and metastasis abilities of lung cancer, and the attenuation of Akt function has become a promising strategy for the research and development of anti-lung cancer therapies [12]. Although current therapeutic drugs, including cisplatin, paclitaxel and etoposide, are recommended and efficient for lung cancer treatment, cancer metastasis and chemotherapeutic resistance often occur [13, 14]. Therefore, the discovery of novel anticancer agents for lung cancer is urgently required.

Aspidistra letreae Aver., Tillich and T.A. Le is a new species in the Aspidistra genus that was discovered in 2016 [15]. Traditionally, Aspidistra has been widely used in the forms of tonics, expectorants, diuretics, and treatments for fractures, congestion and snakebites [16-18]. Aspidistra contains rich chemical components, including saponins, lectins, and homoisoflavones. Additionally, this genus is a potential source of secondary metabolites with a broad spectrum of biological activities, including antifungal [19], antitumor [20], antibacterial [21] and cytotoxic activities [22-24]. Previously, phytochemical investigations of active steroidal saponins led to their isolation and characterization, and aspiletrein A (AA) (Fig. 1) showed the greatest cytotoxicity against five human cancer cell lines, including lung adenocarcinoma (LU-1), cervical carcinoma (HeLa), breast adenocarcinoma (MDA-MB231), liver hepatocellular carcinoma (HepG2) and gastric adenocarcinoma (MKN-7) cell lines, with $\mathrm{IC}_{50}$ values less than $12.5 \mu \mathrm{M}$ [25]. In the present study, we continued investigating the in vitro anticancer activities, particularly the antiproliferation, antimigration and anti-invasion activities, of AA in H460, H23 and A549 lung cancer cells. We found that AA suppressed the migration and invasion of these cancer cell lines through Akt signaling. The results of this study might provide scientific information on AA for future anticancer research and development.

\section{Methods}

\section{Test compound and reagents}

Aspiletrein A (AA), a dry powder, was isolated and characterized as previously described [25]. The structure was determined by NMR analysis on a Bruker Avance 500 spectrometer (Bruker, MA, USA), and the HRESIMS was recorded on an Agilent 6545 accurate-mass spectrometer (Agilent, CA, USA). AA: White amorphous powder $[\alpha]^{25}{ }_{\mathrm{D}}-92.0$ (c $\left.0.1, \mathrm{MeOH}\right)$; IR (KBr) $v_{\max }$ $\left(\mathrm{cm}^{-1}\right)$ : 3422, 2928, 1632, 1454, 1379, 1344, 1221, 1165, 1049, 986, 918, 847, 810; ${ }^{1} \mathrm{H}$ NMR $(500 \mathrm{MHz}$, pyridine$\left.d_{5}\right)$ and ${ }^{13} \mathrm{C}$ NMR (125 MHz, pyridine- $\left.d_{5}\right)$, HRESIMS $m /$ $z 891.4522[\mathrm{M}+\mathrm{Cl}]^{-}$(calcd. For $\mathrm{C}_{44} \mathrm{H}_{72} \mathrm{O}_{16} \mathrm{Cl}$, 891.4509) [25]. AA was dissolved in DMSO to yield a stock solution and further diluted in complete medium to the desired concentrations before use. The control samples in the experiments were incubated with $0.1 \%$ DMSO in the culture medium. The final concentration of DMSO was less than $0.1 \%$, which showed no toxicity.

Hoechst 33342, propidium iodide, 3-(4,5-di-methylthiazol-2-yl)-2,5-diphenyltetrazolium bromide (MTT) and dimethyl sulfoxide (DMSO) were obtained from Sigma Chemical, Inc. (St. Louis, MO, USA). Rabbit antiphosphorylated Akt (S473), rabbit anti-Akt and HRPlinked anti-rabbit IgG were purchased from Cell Signaling Technology (Beverly, MA, USA).

\section{Cell culture}

Human lung cancer H460 (HTB-177), H23 (CRL-5800) and A549 (CCL-185) cells were obtained from ATCC

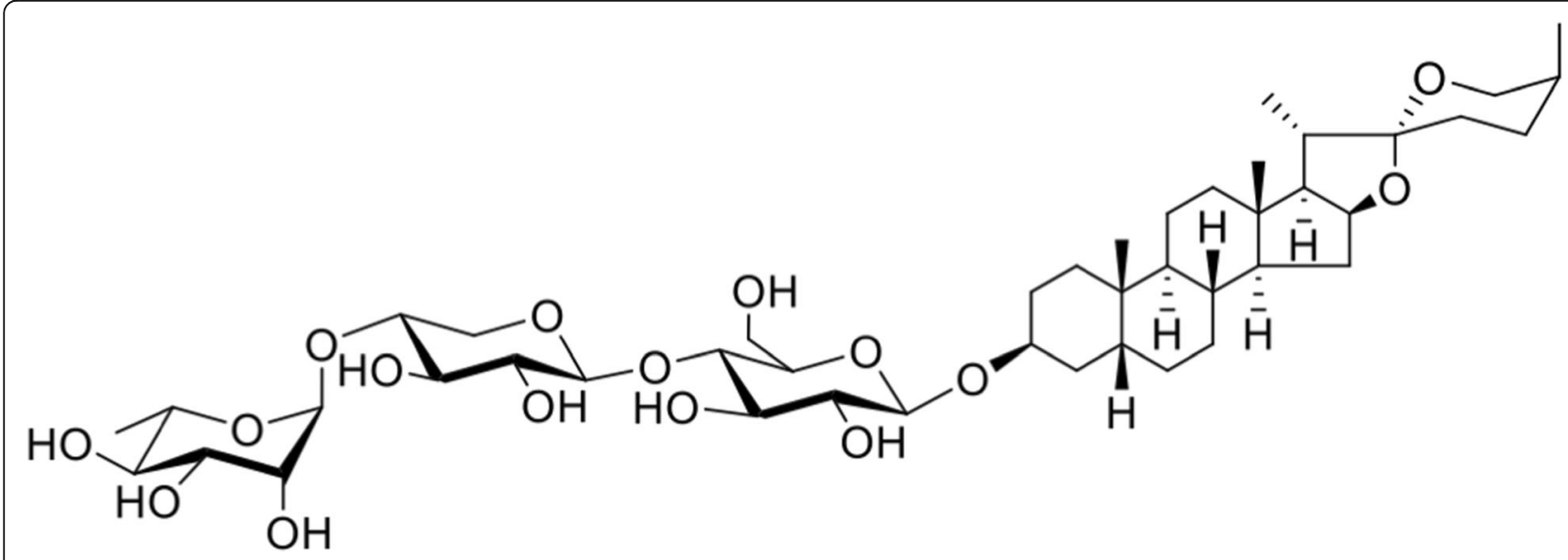

Fig. 1 Chemical structure of Aspiletrein A from Aspidistra letreae 
(Rockville, MD, USA). H460 and H23 cells were cultured in RPMI-1640, and A549 cells were cultured in DMEM. All the cell cultures were supplemented with $10 \%$ fetal bovine serum (FBS), $2 \mathrm{mM} \mathrm{L-glutamine} \mathrm{and} 100$ units/ $\mathrm{mL}$ penicillin/streptomycin and incubated in $5 \% \mathrm{CO}_{2}$ at $37^{\circ} \mathrm{C}$. The media and supplements were obtained from Thermo Fisher Scientific (Waltham, MA, USA).

\section{Cytotoxicity and cell proliferation assays}

Cytotoxicity was assessed by MTT assay, as previously reported [26]. Briefly, $10^{4}$ cells/well were seeded into 96well plates and allowed to attach at $37^{\circ} \mathrm{C}$ in $5 \% \mathrm{CO}_{2}$ overnight. Then, AA $(0-50 \mu \mathrm{M})$ was added and incubated for $24 \mathrm{~h}$. The cells were washed with PBS, and $100 \mu \mathrm{L}$ of $500 \mu \mathrm{g} / \mathrm{mL}$ MTT solution was added to each well. After incubation for $3 \mathrm{~h}$, the formazan crystals were solubilized with $100 \mu \mathrm{L}$ DMSO. The optical absorption of the formazan product was measured at $570 \mathrm{~nm}$ using a microplate reader (Perkin Elmer VICTOR3/Wallac1420), and DMSO was used as the blank. Cell viability was calculated from the mean values of the data as a percentage of the control. The $\mathrm{IC}_{50}(50 \%$ inhibitory concentration) value was determined by Prism 8 (GraphPad Software, CA, USA).

For cell proliferation assessment, a low number of cells $\left(2 \times 10^{3}\right.$ cells/well $)$ were seeded into 96 -well plates and allowed to attach at $37^{\circ} \mathrm{C}$ in $5 \% \mathrm{CO}_{2}$ overnight. The cells were treated with a noncytotoxic concentration of AA for $48 \mathrm{~h}$, which included the doubling time of the cells (approximately $24 \mathrm{~h}$ ), and cell growth was evaluated by MTT assay, as described above. The data are presented as a percentage of growth in the treated cells compared to that in the control cells.

\section{Cell migration assay}

Cell migration was determined using a wound healing assay [26, 27]. Briefly, a total of $2 \times 10^{5}$ cells/well were seeded into 24-well plates and allowed to attach overnight. After a cell monolayer was formed, a wound space was generated using a micropipette tip. The cells were then washed with PBS and treated with various concentrations of AA in low-serum medium (1\% FBS) for $48 \mathrm{~h}$. The wound spaces were imaged and quantified as a relative migration level compared to that in the control cells.

\section{Cell invasion assay}

A total of $3 \times 10^{4}$ cells/well in low-serum medium (1\% FBS) were seeded in Matrigel-coated Transwell ${ }^{\circ}$-Clear Inserts with polyester membrane, and complete medium (10\% FBS) was added to the lower chamber. The cells were incubated with various concentrations of AA for $24 \mathrm{~h}$. The cells on the upper side of the membrane were removed with cotton swabs, and the cells attached to the underside of the membrane were fixed with cold methanol at $-20^{\circ} \mathrm{C}$ for $5 \mathrm{~min}$, stained with $10 \mu \mathrm{g} / \mathrm{mL}$ DAPI for $15 \mathrm{~min}$ and visualized by fluorescence microscopy (Nikon Inverted Microscope Eclipse Ti-U Ti-U/B, NY, USA). Five random fields were captured and analyzed. The data are presented as the percentage of invaded cells in the treated cells compared to that in the control cells.

\section{Western blot analysis}

A total of $7.5 \times 10^{5}$ cells/dish were seeded into $60-\mathrm{mm}$ cell culture dishes overnight. The cells were treated with various concentrations of $\mathrm{AA}$ for $24 \mathrm{~h}$ and lysed in lysis buffer (containing $20 \mathrm{mM}$ Tris- $\mathrm{HCl}$ pH 7.5, $1 \mathrm{mM}$ $\mathrm{MgCl}_{2}, 150 \mathrm{mM} \mathrm{NaCl}, 20 \mathrm{mM} \mathrm{NaF}, 0.5 \%$ sodium deoxycholate, $1 \%$ nonidet- $40,0.1 \mathrm{mM}$ phenylmethylsulfonyl fluoride, and protease inhibitor cocktail (Corning, NY, USA)) on ice for $40 \mathrm{~min}$. The supernatants were collected by centrifugation at $12,000 \mathrm{xg}$ at $4{ }^{\circ} \mathrm{C}$ for $15 \mathrm{~min}$. The protein content was quantified by a BSA protein assay kit (Thermo Fisher Scientific, MA, USA). Protein lysate was boiled in $6 \mathrm{X}$ sampling at $95^{\circ} \mathrm{C}$ for $5 \mathrm{~min}$. Aliquots $(60 \mu \mathrm{g})$ of protein were separated in SDSpolyacrylamide gels and electrotransferred onto polyvinyl difluoride (PVDF) membranes. The membranes were blocked in 5\% skim milk in Tris-buffered saline with $0.75 \%$ Tween 20 (TBS-T) for $1 \mathrm{~h}$ at room temperature, incubated with rabbit primary antibodies against pAkt (S437) or Akt at $4{ }^{\circ} \mathrm{C}$ overnight, and incubated with secondary antibodies at room temperature for $2 \mathrm{~h}$. An antiglyceraldehyde-3-phosphate dehydrogenase (GAPDH) antibody was used as a loading control. The proteins were visualized by an enhanced chemiluminescence system using Immobilon Western chemiluminescent HRP substrate (Millipore, MA, USA) and quantified by ImageJ software. The full-length blots are presented in Supplementary figures.

\section{Statistical analysis}

The data are presented as the mean \pm SEM obtained from three independent experiments and analyzed by Prism 8 (GraphPad Software, CA, USA). Student's T-test was used to determine statistical significance between two groups, and one-way ANOVA with Tukey's multiple comparison test was used for multiple groups. $P$-values less than 0.05 were considered significantly different.

\section{Results}

Cytotoxicity of AA on $\mathrm{H} 460, \mathrm{H} 23$ and A549 human lung cancer cells

A previous study demonstrated that AA exhibited the strongest cytotoxicity among isolated saponins and exerted potent effects against the LU-1 cell line, with an $\mathrm{IC}_{50}$ value of $9.94 \pm 2.15 \mu \mathrm{M}$ [25]. The cytotoxic effect was extensively investigated in $\mathrm{H} 460, \mathrm{H} 23$ and A549 
non-small cell lung cancer cells by MTT assay. The results showed that treatment with AA caused a dose-dependent decrease in cell survival (Fig. 2). AA exhibited significant cytotoxicity against the H460, H23 and A549 cell lines, especially at higher doses $(\geq 25 \mu \mathrm{M})$, with $\mathrm{IC}_{50}$ values of $15.13 \pm 4.86,10.10 \pm 2.93$ and $8.78 \pm 3.08 \mu \mathrm{M}$, respectively (Table 1). AA exhibited less cytotoxicity against normal bronchial epithelial cells, with $\mathrm{IC}_{50}$ values of $26.09 \pm$ $4.08 \mu \mathrm{M}$. The selectivity index calculated as the $\mathrm{IC}_{50}$ of normal cells $/ \mathrm{IC}_{50}$ of cancer cells, demonstrated that $\mathrm{AA}$ has a selectivity index in the range of 1.7-2.9, indicating that this compound preferentially induced cytotoxicity in lung cancer. Generally, the present results are in good agreement with our previous study [25].

Furthermore, the effect of AA on apoptotic regulatory proteins was examined. Western blot analysis revealed that antiapoptotic Bcl-2 and Mcl-1 were gradually decreased in response to AA treatment, whereas no change was observed in proapoptotic Bax. These data indicated that AA-induced lung cancer cell death might be caused by downregulation of the Mcl-1 and $\mathrm{Bcl}-2$ levels.

\section{Anti-proliferative effect of AA on $\mathrm{H} 460, \mathrm{H} 23$ and A549 human lung cancer cells}

Uncontrolled cell growth is recognized as an important feature of cancer [29]. To determine whether AA was able to suppress cancer cell growth, the antiproliferative effect of AA was examined. Lung cancer cells were treated with low doses $(0-12.5 \mu \mathrm{M})$ of AA for $48 \mathrm{~h}$, and cell proliferation was evaluated by MTT assay. The results showed that AA concentrations lower than $6.25 \mu \mathrm{M}$ did not show any significant effect on the proliferation of $\mathrm{H} 460$ and A549 cells and that $3.13 \mu \mathrm{M}$ AA did not show any significant effect on the proliferation of $\mathrm{H} 23$ cells up to $72 \mathrm{~h}$ (Fig. 3). However, at a higher dose of AA $(12.5 \mu \mathrm{M})$, cell proliferation was dramatically decreased at both $48 \mathrm{~h}$ and $72 \mathrm{~h}$. The reduction in the cell numbers after treatment with AA was mainly caused

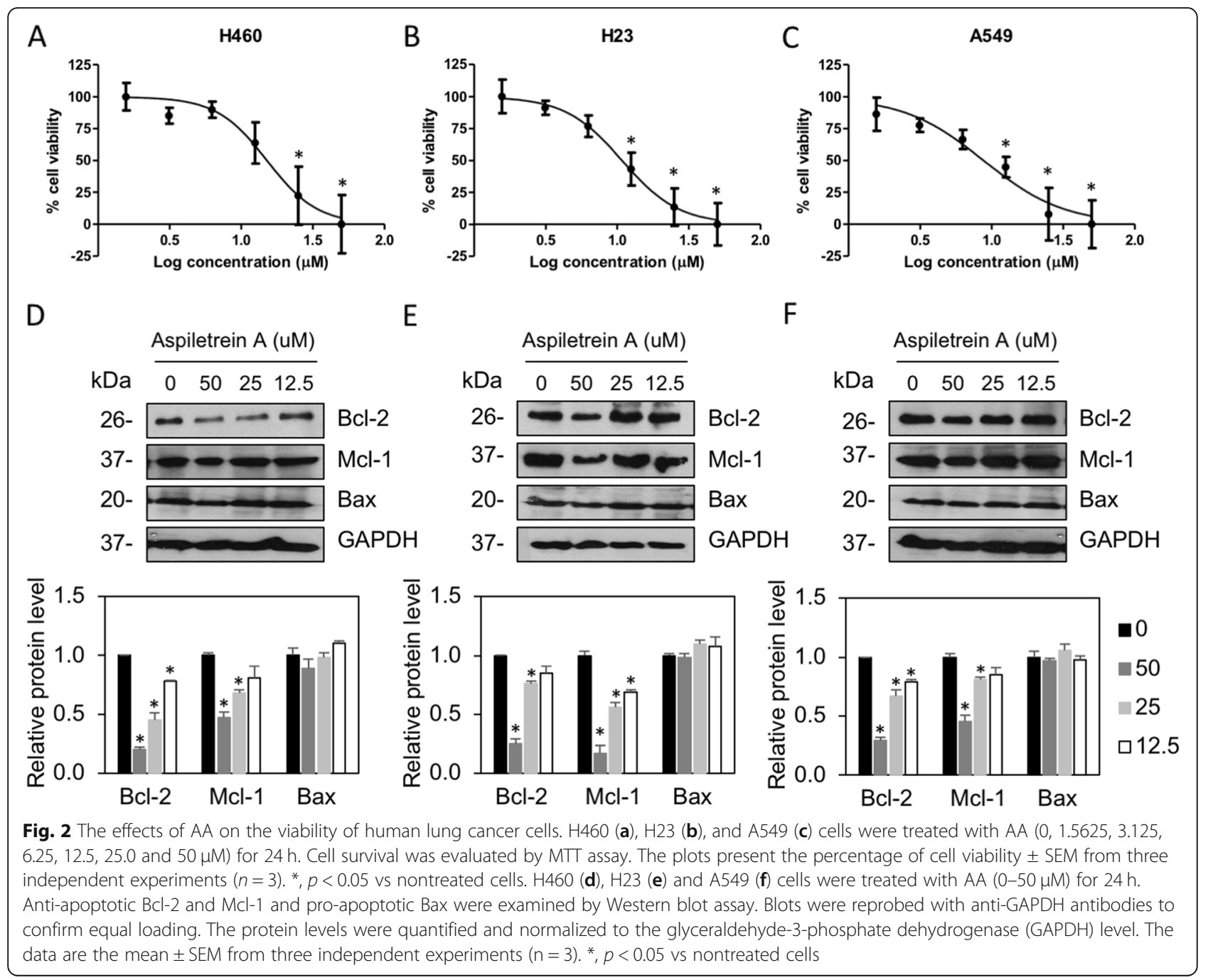


Table 1 Cytotoxicity of AA against human lung cancer and human bronchial epithelial cell lines

\begin{tabular}{|c|c|c|c|c|}
\hline Lung cancer cell lines & ${ }^{\mathrm{a}} \mathrm{C}_{50}(\mu \mathrm{M} \pm \mathrm{SD})$ & Bronchial epithelial cell line & ${ }^{\mathrm{a}} \mathrm{I} C_{50}(\mu \mathrm{M} \pm \mathrm{SD})$ & ${ }^{b} \mathrm{SI}$ \\
\hline $\mathrm{H} 460$ & $15.13 \pm 4.86$ & BEAS-2B & $23.09 \pm 4.08$ & 1.72 \\
\hline $\mathrm{H} 23$ & $10.10 \pm 2.93$ & & & 2.58 \\
\hline A549 & $8.78 \pm 3.08$ & & & 2.97 \\
\hline
\end{tabular}

${ }^{a}$ Concentration that inhibits cell viability by $50 \% .{ }^{b}$ Selectivity index $=I C_{50}$ of normal cells $/ \mathrm{C}_{50}$ of cancer cells [28]

by the cytotoxicity of AA rather than its actual effect on cell growth.

\section{Anti-migration and anti-invasion effects of AA on $\mathrm{H} 460$, H23 and A549 human lung cancer cells}

Since cell migration and invasion are required for cancer metastasis, the negative effect of AA on these metastatic phenotypes was investigated. A wound healing assay was performed in cells treated with nontoxic doses $(0-$ $6.25 \mu \mathrm{M})$ of AA in low-serum medium to avoid the interference of antiproliferative activity. The results demonstrated that the amount of lung cancer cell migration to close the wound space was attenuated by AA, and the wound area that remained in the AA-treated group, especially the group treated with a high dose $(6.25 \mu \mathrm{M})$, was obviously greater than that in the control group. AA at doses of $1.56,3.13$ and $6.25 \mu \mathrm{M}$ notably inhibited the migratory behavior of the H460, H23 and A549 cells compared to that of the control cells (Fig. 4). In particular, the antimigration effects of AA on $\mathrm{H} 460$ cells was initially observed at a low dose of $0.78 \mu \mathrm{M}$. The mobility of $\mathrm{H} 460$ cells decreased to 55, 43, 40 and $34 \%$ in response to $0.78,1.56,3.13$ and $6.25 \mu \mathrm{M} \mathrm{AA}$, respectively. However, cell migration was decreased to approximately 75,73 , and $36 \%$ in $\mathrm{H} 23$ cells treated with 1.56 , 3.13 and $6.25 \mu \mathrm{M}$ AA, respectively. The pattern of AA activity on A549 cells was similar to that of its activity on $\mathrm{H} 23$ cells. These results indicated that AA possessed the ability to inhibit lung cancer cell migration.
Furthermore, the effect of AA on NSCLC invasion was evaluated by Transwell invasion assay. Compound AA at a concentration of $6.25 \mu \mathrm{M}$ strongly attenuated the invasive capabilities of all the cells at $24 \mathrm{~h}$, and the most significant result was observed in A549 cells (Fig. 5). Fluorescence microscopy images revealed a reduction in the number of invaded cells in the treated samples compared to the control samples. Taken together, these results indicated the potent antimetastatic activity of AA in NSCLC.

\section{AA-mediated suppression of human lung cancer cell migration and invasion via Akt signaling}

Akt signaling has been reported to govern sporadic cancer [11], and phosphorylated Akt $\left(\mathrm{pAkt}^{\mathrm{S} 473}\right)$ and total Akt were investigated. Western blot analysis revealed that the pAkt level was markedly downregulated in all the examined cells in a dose-dependent manner (Fig. 6). The pAkt/total Akt ratio observed in H460, H23 and A549 cells was clearly reduced by $0.32-, 0.42-$ and 0.35 fold in response to $62.5 \mu \mathrm{M}$ AA and by 0.11-, 0.38 - and 0.29 -fold in response to $12.5 \mu \mathrm{M}$ AA, respectively, whereas the total Akt levels were unchanged. These results indicated that pAkt/Akt participates in the antimetastatic effect of AA in human lung cancer cells.

\section{Discussion}

Non-small cell lung carcinoma is the most common type of lung cancer, and metastasis and apoptosis dysregulation are major obstacles that contribute to its poor
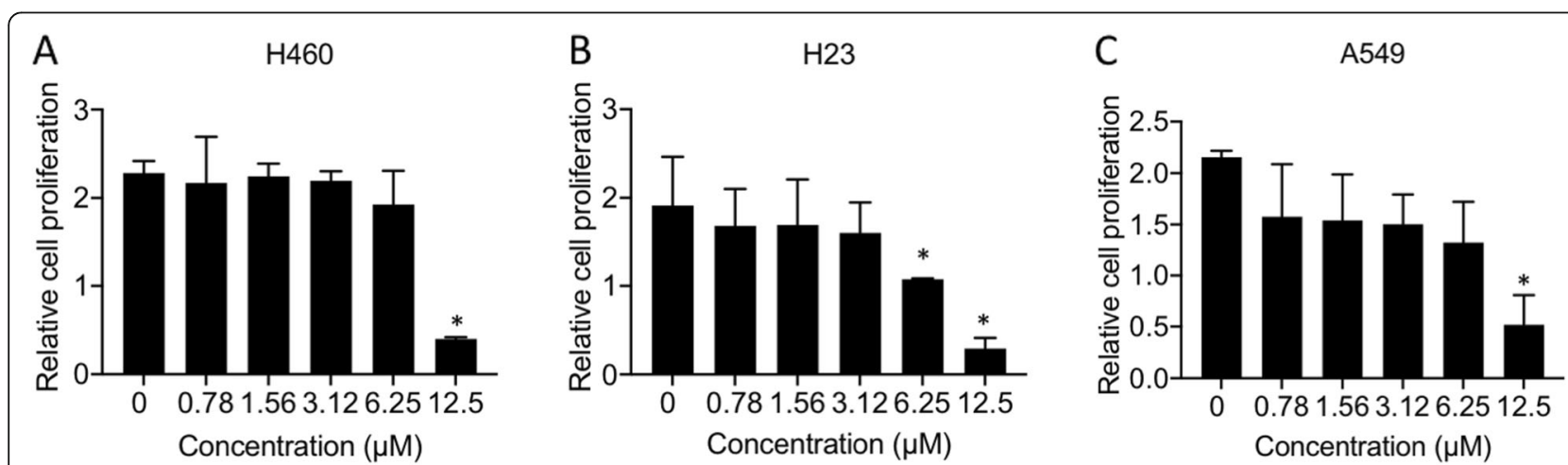

Fig. 3 Anti-proliferative effect of AA on human lung cancer cells. H460 (a), H23 (b) and A549 (c) cells were treated with AA (0-12.5 $\mu$ M) for 48 h. Cell growth was evaluated by MTT assay. The plots present the relative cell proliferation \pm SEM from three independent experiments $(n=3)$. ${ }^{*}$ $p<0.05$ vs nontreated cells 

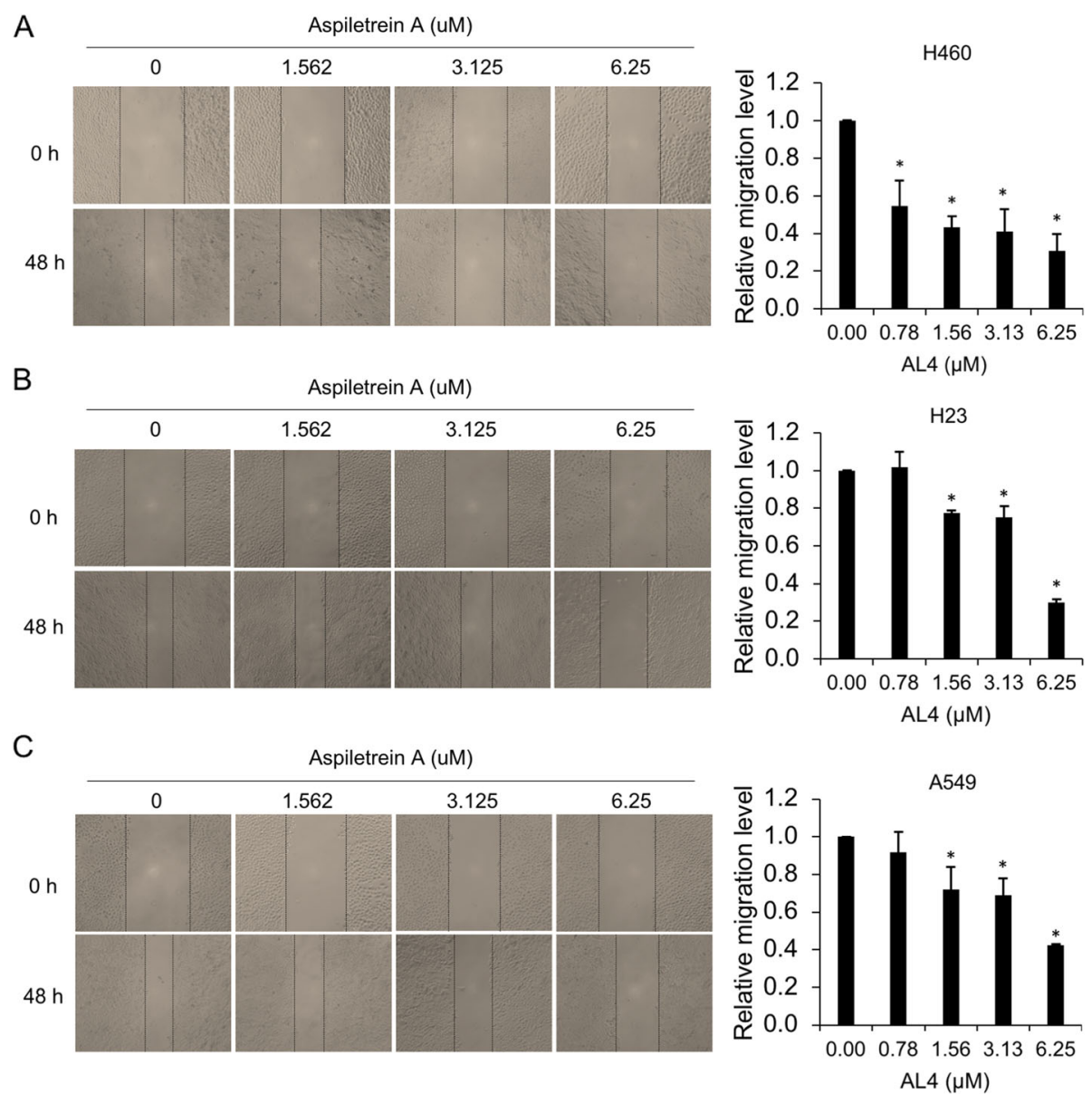

Fig. 4 Antimigration effects of AA on human lung cancer cells. H460 (a), H23 (b) and A549 (c) cells were treated with AA (0-6.25 $\mu \mathrm{M})$ for 48 h. Cell migration was evaluated by wound healing assay. The wound area was calculated and is presented as a relative migration level compared to that in the control group. The data are the mean \pm SEM from three independent experiments $(n=3) . *, p<0.05$ vs nontreated cells

clinical outcome [1]. Therapeutic approaches, therefore, remain a challenge for anticancer drug discovery. Natural compounds from the plant genus Aspidistra have been shown to possess anticancer properties because they contain up to one hundred types of biologically active saponins [22-24]. These properties are mainly attributed to the presence of polysaccharides and their derivatives [30, 31]. Previous studies reported that AA may have potential activities against cancers [25]. However, the anticancer activities of AA with respect to cancer cell proliferation and metastasis have not yet been elucidated. We reported here, for the first time, the potent pharmacological activities of AA from the endemic species Aspidistra letreae on the proliferation, invasion, and migration abilities of $\mathrm{H} 460, \mathrm{H} 23$ and A549 cells.

Several studies have reported that steroidal saponins exert strong tumor suppressive effects, including induction of apoptosis, and are intriguing candidates for anticancer research and development [30-32]. Since the dysregulation of cell death due to either insensitivity to cell death signals or overexpression of survival factors contributes to unresponsiveness to therapies, new compounds that target cancer cell death are of interest [33, 34]. As mentioned above, AA exhibited strong cytotoxicity against the examined cancer cells, with $\mathrm{IC}_{50}$ values ranging from 8.78 to $15.13 \mu \mathrm{M}$, which is consistent with a previous study on other human cancer cell types [25]. In addition, AA exhibits greater cytotoxicity in cancer cells than normal bronchial epithelial cells, with an approximately 2 -fold selectivity index. The greater number is considered a higher selectivity for cancer cells [28]. Since Bcl-2 family proteins play important roles in the regulation of apoptosis, a type of programmed cell death, the balance of anti- and pro-apoptotic proteins determine the fate of the cells [35]. The irregular expression of proteins, including the upregulation of antiapoptotic or the downregulation of proapoptotic proteins in this family, commonly occurs in lung cancer cells [36]. The remodulation of protein expression is, therefore, a promising target for the treatment of lung cancer. It has been 

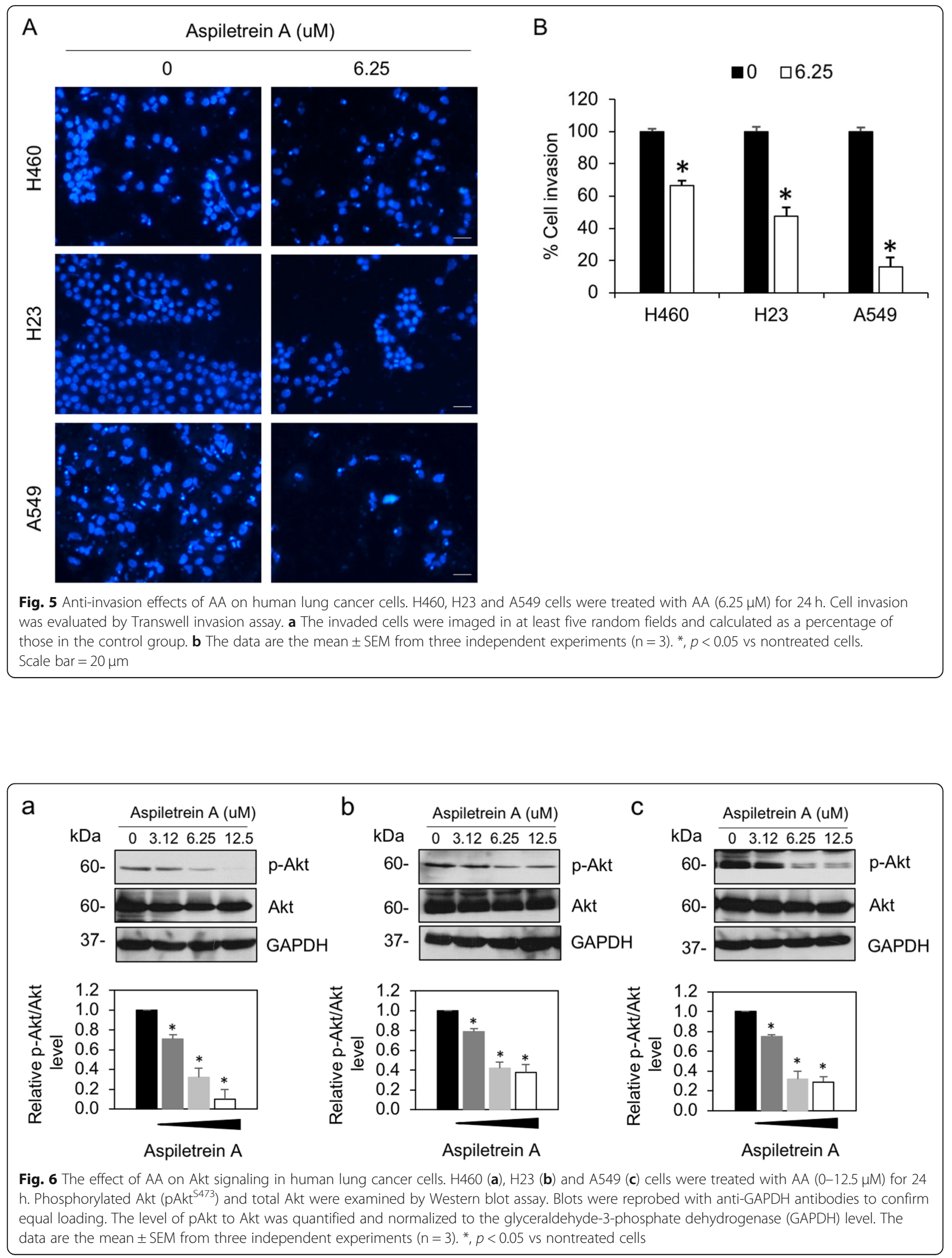
reported that saponin-related compounds induce lung cancer cell apoptosis by increasing the ratio of proapoptotic Bax/antiapoptotic Bcl-2 and decreasing antiapoptotic Mcl-1 [35, 37]. Similar to our findings, AA downregulated Bcl-2 and Mcl-1, facilitating cell death. Although the Bax level was not affected by this compound, the overall antiapoptotic signals were strongly suppressed, driving an imbalance in the Bcl-2 family that was favorable to the cell death response.

Notably, the high proliferation of cancer cells results from oncogenic transformation [38, 39]. Aberrant cell division expands a population of cancer cells with genetic instability that results in defective normal tissue functions. The limitation of cancer cell growth not only facilitates the efficacy of chemotherapy or surgery to remove cancer but also reduces the probability of cancer metastasis [40]. It has been reported that a steroidal saponin, timosaponin AIII, was able to suppress lung cancer cell growth in vivo [41]. However, our study demonstrated that a significant change in cell proliferation was observed only in cells treated with high doses of AA (Fig. 2) that are cytotoxic concentrations. The antiproliferative effect presented might be, at least in part, due to AA-mediated cell death, and the pharmacological efficacy of steroidal saponins relies heavily on polysaccharide substituents on the aglycone moiety [33, 34]. Therefore, the molecular mechanism of this effect of AA was not further deeply considered.

Cancer migration and invasion are essential steps for cancer metastasis [42]. The reorganization and morphological changes facilitate cell dissemination from the cancer tissue [8]. The secretion of enzymes, including the matrix metalloproteinase (MMP) family that degrade the extracellular environment, eases cancer cell invasion into nearby blood circulation or the lymphatic system [8]. Due to these aggressive behaviors of cancer and the physiological properties of secondary organs achieved by lung cancer cells, the chemotherapies currently available are less efficient against metastatic cancer [39]. New therapeutic agents, therefore, mostly focus on suppressing cancer metastasis [43]. A recent study revealed that diosgenin, a steroidal saponin, exhibited antimetastatic activity in human prostate cancer cells through the downregulation of MMP expression [44]. We also found that treatment with a low dose of AA markedly reduced the capacity of the examined cells to migrate and invade.

Akt signaling plays an important role in cancer survival, proliferation and metastasis [11]. Akt signaling is commonly deregulated in cancers; in particular, Akt is overactivated in human lung cancer [45]. Akt, a serine/ threonine kinase, is phosphorylated and activated by several external stimuli through transmembrane proteins, including receptor tyrosine kinases, integrins and cytokine receptors [11]. The transmission of signals from these transmembrane proteins triggers the kinase enzymatic cascade that contributes to Akt phosphorylation by phosphoinositide-dependent kinase-1 (PDK1). pAkt governs several downstream signaling pathways related to cancer metastasis, including epithelial to mesenchymal transition (EMT), actin stress fiber reorganization and MMP expression [46, 47]. Inhibition of Akt function by either chemical inhibitors or RNA interference contributes to abrogating cell motility and invasion [46, 48], suggesting that Akt is an intriguing antimetastatic target. In addition, the regulatory role of Akt in cell proliferation has also been reported to occur through various downstream effectors. For example, Akt activation induces GSK3b/cyclinD1-mediated cell proliferation [49]. Akt signaling was shown to downregulate p27, a cyclindependent kinase inhibitor that induces cell cycle arrest [50]; in contrast, attenuation of Akt function conversely increases p27-suppressed cancer cell growth [51]. We found that AA significantly suppressed the pAkt levels, indicating that $\mathrm{AA}$ is a promising compound for further research and development.

\section{Conclusions}

This study reported, for the first time, the antiproliferation, anti-migration, and anti-invasion effects of AA on human non-small cell lung cancer cells. Compound AA was able to decrease cell viability in three human lung cancer cell lines, H460, H23 and A549 cells, whereas a smaller effect on cell proliferation was observed in these cell lines. Notably, AA significantly inhibited the migration and invasion of these examined cells via attenuation of the p-Akt/Akt signaling pathway, suggesting that AA may be a promising agent for antimetastatic therapy. Further relevant molecular mechanisms and an in vivo study will be conducted to support the potential uses of AA in the future.

\begin{abstract}
Abbreviations
AA: Aspiletrein A; GAPDH: Glyceraldehyde-3-phosphate dehydrogenase; SCLC : Small-cell lung carcinoma; NSCLC: Non-small cell lung carcinoma; HRES IMS: High-resolution electrospray ionization mass spectrometry; $I C_{50}: 50 \%$ Inhibitory concentration; MTT: 3-(4,5-Di-methylthiazol-2-yl)-2,5-

diphenyltetrazoliumbromide; DMSO: Dimethyl sulfoxide; FBS: Fetal bovine serum; PBS: Phosphate-buffered saline; Akt: Protein kinase B; pAkt: Phosphorylated Akt; MMPs: Matrix metalloproteinases
\end{abstract}

\section{Supplementary Information}

The online version contains supplementary material available at https://doi. org/10.1186/s12906-021-03262-w.

Additional file 1: Fig. S1. The original blot for Fig. 2d. Fig. S2. The original blot for Fig. 2e. Fig. S3 The original blot for Fig. 2f. Fig. $\mathbf{S 4}$ The original blot for Fig. 6 .

\section{Acknowledgements}

We thank Suthaorn Pothongsrisit for experimental advice and preliminary data. 


\section{Authors' contributions}

DVH, HThN and VP designed the search. HMN, DVH, SS and VP performed and analyzed the experiments. HMN, HTN and HBD wrote the original manuscript draft. HMN and VP reviewed and edited the draft. DVH and VP funded the experiments. All the authors have read and approved the manuscript.

\section{Funding}

This work was financially supported by Hue University, Vietnam (DHH201904-101), which provided a research resource for compound isolation experiments, and the Thailand Research Fund, Thailand (MRG6280235), which provided a research resource for in vitro cell culture experiments.

\section{Availability of data and materials}

The data used and analyzed during the current study are available from the corresponding authors (DVH and VP) upon reasonable request.

\section{Declarations}

\section{Ethics approval and consent to participate}

This article does not contain any studies with human participants or animals performed by any of the authors.

\section{Consent for publication}

Not applicable.

\section{Competing interests}

The authors declare that they have no competing interests.

\section{Author details}

'Faculty of Pharmacy, Ton Duc Thang University, Ho Chi Minh City, Vietnam. ${ }^{2}$ Faculty of Pharmacy, Hue University of Medicine and Pharmacy, Hue University, Hue City, Vietnam. ${ }^{3}$ Pharmaceutical Sciences and Technology Graduate Program, Faculty of Pharmaceutical Sciences, Chulalongkorn University, Bangkok 10330, Thailand. ${ }^{4}$ Department of Pharmacology and Physiology, Faculty of Pharmaceutical Sciences, Chulalongkorn University, Bangkok 10330, Thailand. ${ }^{5}$ Preclinical Toxicity and Efficacy Assessment of Medicines and Chemicals Research Cluster, Chulalongkorn University, Bangkok 10330, Thailand.

\section{Received: 13 August 2020 Accepted: 24 February 2021}

\section{Published online: 09 March 2021}

\section{References}

1. Bray F, Ferlay J, Soerjomataram I, Siegel RL, Torre LA, Jemal A. Global cancer statistics 2018: GLOBOCAN estimates of incidence and mortality worldwide for 36 cancers in 185 countries. CA Cancer J Clin. 2018:68:394-424.

2. Santana-Davila R, Szabo A, Arce-Lara C, Williams CD, Kelley MJ, Whittle J. Cisplatin versus carboplatin-based regimens for the treatment of patients with metastatic lung cancer. An analysis of veterans health administration data. J Thorac Oncol. 2014;9:702-9.

3. Kowitdamrong A, Chanvorachote P, Sritularak B, Pongrakhananon V. Moscatilin inhibits lung cancer cell motility and invasion via suppression of endogenous reactive oxygen species. Biomed Res Int. 2013;2013:765894.

4. Maslyar DJ, Jahan TM, Jablons DM. Mechanisms of and potential treatment strategies for metastatic disease in non-small cell lung cancer. Semin Thorac Cardiovasc Surg. 2004;16:40-50

5. Molina JR, Yang P, Cassivi SD, Schild SE, Adjei AA. Non-small cell lung cancer: epidemiology, risk factors, treatment, and survivorship. Mayo Clin Proc. 2008:83:584-94.

6. Zappa C, Mousa SA. Non-small cell lung cancer: current treatment and future advances. Transl Lung Cancer Res. 2016;5:288-300.

7. Howlader N, Noone AM, Krapcho M, Miller D, Brest A, Yu M, Ruhl J, Tatalovich Z, Mariotto A, Lewis DR, Chen HS, Feuer EJ, Cronin KA, editors. SEER cancer statistics review, 1975-2016. Bethesda: National Cancer Institute. https://seer.cancer.gov/csr/1975_2016/, based on November 2018 SEER data submission, posted to the SEER web site, April 2019.

8. Martin TA, Ye L, Sanders AJ, Lane J, Jiang WG. Cancer invasion and metastasis: molecular and cellular perspective. In: Madame curie bioscience database edn: Landes Bioscience; 2013.
9. Suhail Y, Cain MP, Vanaja K, Kurywchak PA, Levchenko A, Kalluri R. Kshitiz: systems biology of cancer metastasis. Cell Syst. 2019;9:109-27.

10. Thakur MK, Ruterbusch JJ, Schwartz AG, Gadgeel SM, Beebe-Dimmer JL, Wozniak AJ. Risk of second lung cancer in patients with previously treated lung cancer: analysis of surveillance, epidemiology, and end results (SEER) data. J Thorac Oncol. 2018;13:46-53.

11. Revathidevi S, Munirajan AK. Akt in cancer: mediator and more. Semin Cancer Biol. 2019;59:80-91.

12. Cheng H, Shcherba M, Pendurti G, Liang Y, Piperdi B, Perez-Soler R. Targeting the PI3K/AKT/mTOR pathway: potential for lung cancer treatment. Lung Cancer Manag. 2014;3:67-75.

13. Comella P, Chiuri VE, De Cataldis G, Filippelli G, Maiorino L, Vessia G, Cioffi R, Mancarella S, Putzu C, Greco E, et al. Gemcitabine combined with either pemetrexed or paclitaxel in the treatment of advanced nonsmall cell lung cancer: a randomized phase II SICOG trial. Lung Cancer. 2010;68:94-8

14. Zhao Y, Wan B, Zhang T, Xu Y, Liu H, Lv T, Zhang F, Zhan P, Song Y. Irinotecan, topotecan, paclitaxel or docetaxel for second-line treatment of small cell lung cancer: a single-center retrospective study of efficiency comparation and prognosis analysis. Transl Lung Cancer Res. 2019;8:829-37.

15. Ly N-S, Tillich H. Aspidistra averyanovii and A. Parviflora (Asparagaceae), two new species Central Vietnam. Phytotaxa. 2016;282:53-60.

16. Cui J-M, Kang L-P, Zhao Y, Zhao J-Y, Zhang J, Pang X, Yu H-S, Jia D-X, Liu C, Yu L-Y, et al. Steroidal saponins from the rhizomes of Aspidistra typica. PLoS One. 2016;11:e0150595.

17. Mori Y, Kawasaki T. A new diosgenin glycoside, Aspidistrin, from Aspidistra elatior Blume. Chem Pharm Bull. 1973;21:224-7.

18. Peng J, Zhao Y, Xu L, Kang L-p, Cui J-m, Yu H-s, Zhang J, Ma B-p. Metabolite profiling of steroidal glycosides in the rhizome of Aspidistra sichuanensis using UPLC/Q-TOF MSE. Int J Mass Spectrom. 2017;415:63-84.

19. Koketsu M, Kim M, Yamamoto T. Antifungal activity against food-borne fungi of Aspidistra elatior Blume. J Agric Food Chem. 1996;44:301-3.

20. Xu XC, Zhang ZW, Chen YE, Yuan M, Yuan S, Bao JK. Antiviral and antitumor activities of the lectin extracted from Aspidistra elatior. Z Naturforsch C J Biosci. 2015;70:7-13.

21. Liang X, Kong L, He M. A new homoisoflavone compound as a potent antibacterial agent from Aspidistra typica Baill. J Chinese Pharm Sci. 2016;25: 700-3.

22. Cui JM, Kang LP, Yu HS, Zhao Y, Xiong CQ, Liu C, Ma BP. Two new furostanol saponins from Aspidistra typica. J Asian Nat Prod Res. 2013;15: $525-31$.

23. Hirai Y, Konishi T, Sanada S, Ida Y, Shoji J. Studies on the constituents of Aspidistra elatior blume I. on the steroids of the underground part. Chem Pharm Bull. 1982;30:3476-84

24. Zuo S-Q, Liu Y-N, Yang Y, Guo Z-Q, Liu C-X, Guo Z-Y, He H-B, Tu X, Zou K. Aspidsaponins $A-D$, four new steroidal saponins from the rhizomes of Aspidistra elatior Blume and their cytotoxicity. Phytochem Lett. 2018;25:12631

25. Ho DV, Hoang HNT, Vo HQ, Nguyen KV, Pham TV, Le AT, Van Phan K, Nguyen HM, Morita H, Nguyen HT. Three new steroidal saponins from Aspidistra letreae plants and their cytotoxic activities. J Nat Med. 2020;74: 591-8.

26. Witayateeraporn W, Arunrungvichian K, Pothongsrisit S, Doungchawee J, Vajragupta O, Pongrakhananon V. a7-nicotinic acetylcholine receptor antagonist QND7 suppresses non-small cell lung cancer cell proliferation and migration via inhibition of Akt/mTOR signaling. Biochem Biophys Res Commun. 2020;521:977-83.

27. Charoenrungruang S, Chanvorachote P, Sritularak B, Pongrakhananon V. Gigantol, a bibenzyl from dendrobium draconis, inhibits the migratory behavior of non-small cell lung cancer cells. J Nat Prod. 2014;77:1359-66.

28. Singh K, Gangrade A, Jana A, Mandal BB, Das NJAO. Design, synthesis, characterization, and antiproliferative activity of organoplatinum compounds bearing a 1, 2, 3-triazole ring. ACS Omega. 2019;4:835-41.

29. Fouad YA, Aanei C. Revisiting the hallmarks of cancer. Am J Cancer Res. 2017;7:1016-36

30. Mimaki Y, Yokosuka A, Kuroda M, Sashida Y. Cytotoxic activities and structure-cytotoxic relationships of steroidal saponins. Biol Pharm Bull. 2001; 24:1286-9.

31. Thakur M, Melzig M, Fuchs $H$, Weng A. Chemistry and pharmacology of saponins: special focus on cytotoxic properties. Botanics Targets Ther. 2011; 1:19-29. 
32. Tong QY, He Y, Zhao QB, Qing Y, Huang W, Wu XH. Cytotoxicity and apoptosis-inducing effect of steroidal saponins from Dioscorea zingiberensis Wright against cancer cells. Steroids. 2012;77:1219-27.

33. Letai A. Cell death and cancer therapy: Don't forget to kill the cancer cell! Clin Cancer Res. 2015;21:5015-20.

34. Wattanathamsan O, Hayakawa Y, Pongrakhananon V. Molecular mechanisms of natural compounds in cell death induction and sensitization to chemotherapeutic drugs in lung cancer. Phytother Res. 2019;33:2531-47.

35. Hao W, Wang S, Zhou Z. Tubeimoside-1 (TBMS1) inhibits lung cancer cell growth and induces cells apoptosis through activation of MAPK-JNK pathway. Int J Clin Exp Pathol. 2015:8:12075.

36. Sun PL, Sasano H, Gao H. Bcl-2 family in non-small cell lung cancer: its prognostic and therapeutic implications. Pathol Int. 2017;67:121-30.

37. Jiang H, Zhao PJ, Su D, Feng J, Ma SL. Paris saponin I induces apoptosis via increasing the $\mathrm{Bax} / \mathrm{BCl}-2$ ratio and caspase-3 expression in gefitinib-resistant non-small cell lung cancer in vitro and in vivo. Mol Med Rep. 2014;9:2265-72.

38. Zhang E, Li W, Yin D, De W, Zhu L, Sun S, Han L. c-Myc-regulated long noncoding RNA H19 indicates a poor prognosis and affects cell proliferation in non-small-cell lung cancer. Tumour Biol. 2016;37:4007-15.

39. Sun YW, Xu J, Zhou J, Liu WJ. Targeted drugs for systemic therapy of lung cancer with brain metastases. Oncotarget. 2017;9:5459-72.

40. Feitelson MA, Arzumanyan A, Kulathinal RJ, Blain SW, Holcombe RF, Mahajna J, Marino M, Martinez-Chantar ML, Nawroth R, Sanchez-Garcia I, et al. Sustained proliferation in cancer: mechanisms and novel therapeutic targets. Semin Cancer Biol. 2015;35(Suppl):25-54.

41. Song XY, Han FY, Chen JJ, Wang W, Zhang Y, Yao GD, Song SJ. Timosaponin Alll, a steroidal saponin, exhibits anti-tumor effect on taxolresistant cells in vitro and in vivo. Steroids. 2019;146:57-64.

42. Bravo-Cordero JJ, Hodgson L, Condeelis J. Directed cell invasion and migration during metastasis. Curr Opin Cell Biol. 2012;24:277-83.

43. Chanvorachote P, Chamni S, Ninsontia C, Phiboonchaiyanan PP. Potential anti-metastasis natural compounds for lung cancer. Anticancer Res. 2016;36: 5707-17.

44. Chen PS, Shih YW, Huang HC, Cheng HW. Diosgenin, a steroidal saponin, inhibits migration and invasion of human prostate cancer PC-3 cells by reducing matrix metalloproteinases expression. PLoS One. 2011;6:e20164.

45. Jin Y, Yuan Y, Yi M, Han H, Liu B, Li Q. Phosphorylated-Akt overexpression is associated with a higher risk of brain metastasis in patients with non-small cell lung cancer. Biochem Biophys Rep. 2019;18:100625-31.

46. Treesuwan S, Sritularak B, Chanvorachote P, Pongrakhananon V. Cypripedin diminishes an epithelial-to-mesenchymal transition in non-small cell lung cancer cells through suppression of Akt/GSK-3 $\beta$ signalling. Sci Rep. 2018;8: 8009.

47. Wu X, Sun L, Wang X, Su P, Li Z, Zhang C, Wang Y, Gao P, Ma R. Breast cancer invasion and metastasis by mPRa through the PI3K/Akt signaling pathway. Pathol Oncol Res. 2016;22:471-6

48. Liang $\mathrm{H}$. Advanced glycation end products induce proliferation, invasion and epithelial-mesenchymal transition of human SW480 colon cancer cells through the PI3K/AKT signaling pathway. Oncol Lett. 2020;19:3215-22.

49. Liu P, Zhu C, Luo J, Lan S, Su D, Wang Q, Wei Z, Cui W, Xu C, Yang X. Par6 regulates cell cycle progression through enhancement of Akt/PI3K/GSK-3 $\beta$ signaling pathway activation in glioma. Faseb. 2020;34:1481-96.

50. Cai J, Lu W, Du S, Guo Z, Wang H, Wei W, Shen X. Tenascin-C modulates cell cycle progression to enhance tumour cell proliferation through AKT/ FOXO1 signalling in pancreatic cancer. J Cancer. 2018;9:4449.

51. Rassidakis GZ, Feretzaki M, Atwell C, Grammatikakis I, Lin Q, Lai R, Claret F-X, Medeiros $\sqcup$, Amin HMJB. Inhibition of Akt increases p27Kip1 levels and induces cell cycle arrest in anaplastic large cell lymphoma. Blood. 2005;105: 827-9.

\section{Publisher's Note}

Springer Nature remains neutral with regard to jurisdictional claims in published maps and institutional affiliations.

Ready to submit your research? Choose BMC and benefit from:

- fast, convenient online submission

- thorough peer review by experienced researchers in your field

- rapid publication on acceptance

- support for research data, including large and complex data types

- gold Open Access which fosters wider collaboration and increased citations

- maximum visibility for your research: over $100 \mathrm{M}$ website views per year

At $\mathrm{BMC}$, research is always in progress.

Learn more biomedcentral.com/submissions 